\title{
Standardized Methods were Established to Measure Symbiotic Nitrogen Fixation in the Various Land-Use System of Planting Legumes Under Field Conditions Calculations of Symbiotic Nitrogen Fixation Accumulation When One Land-Use Type is Converted to Another Crop Rotation
}

\section{Makkies David Lengwati*}

Department of Agriculture, Rural Development, Land Administration and Environmental Affairs (DARDLEA), South Africa

*Corresponding Author: Makkies David Lengwati, Department of Agriculture, Rural Development, Land Administration and Environmental Affairs (DARDLEA), South Africa.
Received: September 29, 2020

Published: August 02, 2021

(C) All rights are reserved by Makkies David Lengwati.

\section{Abstract}

Nitrogen fixation potential and residual effects of selected grain legumes in a South African soil with the back-up of nitrogen economy of pulse crop production in the Nelspruit/Mbombela Lowveld area was studied.

Rhizobium - legume symbiosis and nitrogen fixation under severe conditions and in an arid climate and using kraal manure as a fertilizer in growing vegetables in the home garden were also observations for nitrogen supply to plant growth. Measuring plantassociated nitrogen fixation in agricultural systems has a potential precision of the $\delta^{15} \mathrm{~N}$ natural abundance method in field estimates of nitrogen fixation by crop and pasture legumes in South Africa thus provided influence of mycorrhizal associations on foliar $\delta^{15} \mathrm{~N}$ values of legume and non-legume shrubs and trees in the fynbos of South Africa, Western Cape province with implications for estimating $\mathrm{N}_{2}$ fixation using the ${ }^{15} \mathrm{~N}$ natural abundance method.

A cropping system assessment framework - evaluating effects of introducing legumes into crop rotations with $\mathrm{N}_{2}$ - fixation in field settings: estimations based on natural ${ }^{15} \mathrm{~N}$ abundance was categorized as priority. Root exudates as mediators of mineral acquisition in low-nutrient environments and the effect of temperature on nodulation and nitrogen fixation by five grain legumes were tested under field conditions without Rhizobium strains applied.

Variation in $\mathrm{N}_{2}$ fixation and $\mathrm{N}$ contribution by five grain legumes varieties grown in the same agro - ecologies, measured using ${ }^{15} \mathrm{~N}$ natural abundance results were obtainable. This study based it's importance on African legumes a vital but under - utilized resources. Those Grain legumes increases soil - $\mathrm{N}$ fertility in cereal systems through nitrate sparing and $\mathrm{N}_{2}$ fixation in contrast to inorganic fertilizer application. Atmospheric nitrogen is a reliable standard for natural ${ }^{15} \mathrm{~N}$ abundance measurements. Methodologies for estimating nitrogen transfer between legumes and companion species in agro - ecosystems was a review of ${ }^{15} \mathrm{~N}$ - enriched techniques which was put into practice.

Keywords: Fertilizer; $\mathrm{N}_{2} ; \delta^{15} \mathrm{~N}$

\section{Abbreviations}

B. value: This value represents the slope of the line between the predictor variable and the dependent variable. So, for variable 1 , this would mean that for every one unit increase in variable 1 , the dependent variable increases by 1.57 units; ICRAF: International Centre for Research in Agroforestry; ARC: Agricultural Research Council; FSR/E: Farmers Support Research/Agricultural Extensioners; ICRISAT: International Crop Research Institute of Semi-

Citation: Makkies David Lengwati. "Standardized Methods were Established to Measure Symbiotic Nitrogen Fixation in the Various Land-Use System of Planting Legumes Under Field Conditions Calculations of Symbiotic Nitrogen Fixation Accumulation When One Land-Use Type is Converted to Another Crop Rotation". Acta Scientific Agriculture 5.9 (2021): 42-52. 
Standardized Methods were Established to Measure Symbiotic Nitrogen Fixation in the Various Land-Use System of Planting Legumes Under Field Conditions Calculations of Symbiotic Nitrogen Fixation Accumulation When One Land-Use Type is Converted to Another Crop Rotation

Arid Tropics; $\mathrm{CH}_{4}$ : Ammonium Di-Atomic Molecules; $\mathrm{N}_{2} \mathrm{O}$ : Nitrous Oxide Di-Atomic Molecules; $\mathrm{NO}_{\mathrm{X}}$ : Nitrate; $\mathrm{N}_{2}$ : Nitrogen Gas (Nitrogen Fixed); F. M. C: Field Moisture Capacity; ppm: Parts per million; Dundee: Town in the Province of KwaZulu/Natal; DAFF: Department of Agriculture Forestry ang Fisheries (RSA)

\section{General Introduction and Study Background}

A new version of the CENTURY model (NGAS-CENTURY) has been developed to simulate trace gas production. The NGAS-CENTURY version uses a daily time step and can simulate daily $\mathrm{CH}_{4}$ consumption, and $\mathrm{N}_{2} \mathrm{O}, \mathrm{NO}_{\mathrm{x}}$ and $\mathrm{N}_{2}$ gas fluxes in crop production plants [1] (The main nutrients a plant needs are nitrogen, phosphorus and potassium (Table 1).

\begin{tabular}{|l|l|l|c|}
\hline $\begin{array}{l}\text { From air or } \\
\text { water }\end{array}$ & From soil & Fertilizers & Or Manure \\
\hline & $\begin{array}{c}\text { Primary } \\
\text { Nutrients }\end{array}$ & $\begin{array}{c}\text { Secondary } \\
\text { Nutrients }\end{array}$ & $\begin{array}{c}\text { Micro/trace } \\
\text { Nutrients }\end{array}$ \\
\hline Hydrogen & Nitrogen & Calcium & Iron \\
\hline Carbon & Phosphorus & Magnesium & Manganese \\
\hline & & & Copper \\
\hline Oxygen & Potassium & Sulfur & Boron \\
\hline & & & Molybdenum \\
\hline & & & Chlorine \\
\hline & & & Cobalt \\
\hline
\end{tabular}

Table 1: Nutrients and their sources.

T Nagur, B Diwakar and DL Oswalt. Management procedures for pearl millet improvement, ICRISAT, Skill Development Series no.

$$
\text { 5., } 1992 .
$$

Nitrogen is usually the second most deficient nutrient and once you have taken care of the phosphorus needs of your crops, you can expect an additional increase in yield by applying nitrogen.

Legumes grow best on mildly acid to slightly basic light soils with at least a moderate fertility. The crops are very susceptible to water-logging, although some legume plants weakened by a $\mathrm{pH}$ (KCL) lower than 4.3, the plants are also harmed free calcium in the soil. Since, after inoculation, the plants are nitrogen fixing, no nitrogen fertilization is necessary. Similarly on a rare occasion the inoculation may be slow to take effect and the plants will show a nitrogen deficiency.
$\mathrm{N}_{2} \mathrm{O}$ fluxes are linked primarily to anaerobic conditions and are thus more related to the soil type, primarily texture, and landscape position, than to land use per se (unless $\mathrm{N}$ fertilizers are applied) [2]. On a given soil type and landscape position, $\mathrm{N}_{2} \mathrm{O}$ emissions are directly related to above-ground carbon and nitrogen stocks (and cycling), unless nitrogenous fertilizers are applied [3]. Given equal above-ground carbon stocks, $\mathrm{N}_{2} \mathrm{O}$ fluxes are not affected by plant biodiversity [3].

Nitrogen is readily available to plant roots in the form of nitrate nitrogen. Because nitrogen is easily leached into lower layers of the soil, consider postponing application until plants are well developed.

\section{Materials and Methods}

Excessive application of nitrogen without the simultaneous application of potassium and phosphate may promote leaf and stem growth without increasing yield. Yield may even be reduced. (IITA Research Guide 60 1997). Therefore, soil sampling is necessary before planting any soil nutrients utilizing crop (A Table 2: a description of chemical and/or physical properties of soil collected from the Nelspruit location before planting of the grain legumes).

\begin{tabular}{|l|c|c|}
\hline Parameters & Unit & Mean \\
\hline pH (KCl) & & 5.95 \\
\hline Soil organic carbon (SOC) & $\%$ & 0.18 \\
\hline Nitrogen (N) & $\mathrm{mg} \mathrm{kg}^{-1}$ & 7.65 \\
\hline Phosphorus (P) & $\mathrm{mg} \mathrm{kg}^{-1}$ & 19.91 \\
\hline Potassium (K) & $\mathrm{mg} \mathrm{kg}^{-1}$ & 38.86 \\
\hline Calcium (Ca) & $\mathrm{mg} \mathrm{kg}^{-1}$ & 143.50 \\
\hline Magnesium (Mg) & $\mathrm{mg} \mathrm{kg}^{-1}$ & 37.66 \\
\hline Zinc (Zn) m & $\mathrm{mg} \mathrm{kg}^{-1}$ & 3.19 \\
\hline Clay $\%$ & $\%$ & 8.00 \\
\hline
\end{tabular}

Table 2: A description of chemical and/or physical properties of soil collected from the Nelspruit location before planting of the grain legumes.

Values of legumes for data analysis are as follows

The B value used for estimating \%Ndfa in this study for legumes, Groundnut will be $-2.70 \%$ [4], Bambara groundnut will be $-1.40 \%$ [4], cowpea will be $-1.759 \%$ [5], blackgram will be $-2.20 \%$ [6], and mungbean will be $-1.14 \%$ [6]. 
Standardized Methods were Established to Measure Symbiotic Nitrogen Fixation in the Various Land-Use System of Planting Legumes Under Field Conditions Calculations of Symbiotic Nitrogen Fixation Accumulation When One Land-Use Type is Converted to Another Crop Rotation

\section{Analysis of ${ }^{15} \mathrm{~N} /{ }^{14} \mathrm{~N}$ isotopic ratio}

In order to determine the ${ }^{15} \mathrm{~N} /{ }^{14} \mathrm{~N}$ ratio of plant samples, about $2.0 \mathrm{mg}$ each of both legume and reference plant material were weighed into tin capsules, loaded on to the mass spectrometer, and analysed using a Carlo Erba NA1500 elemental analyzer (Fisons Instruments SpA, Strada, Rivoltana, Italy) coupled to a Finan MAT252 mass spectrometer (Finnigan, MAT CombH, Bremen, Germany) via a Conflo II open-split device. An internal standard (Nasturtium spp.) was included in every five runs to correct machine errors during isotopic fractionation. The isotopic analysis was similarly done for the reference plants.

\section{Nitrogen content}

The $\mathrm{N}$ content of above ground biomass was determined as the product of \% $\mathrm{N}$ and biomass as (Pausch., et al. 1996).

\section{Amount of $\mathrm{N}_{2}$ fixation}

For this work, however, the natural abundance technique as described by [7] was used. This is a method that is based on mass spectrometric analysis of ${ }^{15} \mathrm{~N} /{ }^{14} \mathrm{~N}$ isotope ratio in finely ground plant tissues. This finely ground plants material is weighed $(2.0$ $\mathrm{mg}$ /sample) into aluminium capsules, loaded onto a Carlo Erba NA 150 Elemental Analyzer coupled to a Finnigan MAT 252 Mass Spectrometer (Finnigan MAT GmbH, Bremen, Germany) via a Conflo II Open-split system, and anlyzed for $\% \mathrm{~N}, \delta^{15} \mathrm{~N} \% \mathrm{C}$ and $\delta^{13} \mathrm{C}$ values. The ${ }^{15} \mathrm{~N}$ natural abundance is then expressed in a relative delta $(\delta)$ notation, which is the \% deviation of the ${ }^{15} \mathrm{~N}$ natural abundance of the sample from atmosphere $\mathrm{N}_{2}\left(0.366\right.$ atom $\left.\%{ }^{15} \mathrm{~N}\right)$. The isotopic composition is thereafter measured according to [8].

N-fixed: The amount of $\mathrm{N}$-fixed was calculated as (Maskey., et al. 2001):

$\mathrm{N}$-fixed $=\% \mathrm{Ndfa}$ x legume biomass $\mathrm{N}$

\section{Soil N uptake}

Soil N uptake was measured by subtracting value in plants (g) of $\% \mathrm{Ndfa}$ (from soil $\mathrm{N}$ content and resulted in soil $\mathrm{N}$ utilised by plants during the growth period until harvesting).

\section{Statistical analysis}

All data collected were subjected to statistical analysis using STATISTICA software program version 10. Shoot biomass and symbiotic parameters such as $\mathrm{N}$ concentration and $\mathrm{N}$ content, $\delta^{15} \mathrm{~N}$, $\% \mathrm{Ndfa}, \mathrm{N}$-fixed and soil $\mathrm{N}$-uptake were compared between plant species using a one-way ANOVA. Where treatment means were dif- ferent, Fisher's least significant difference (LSD) was used to separate the means at $\mathrm{p} \leq 0.05$.

Growth and symbiotic $\mathrm{N}_{2}$ fixation of five pulse legumes planted at Nelspruit, South Africa

\section{Introduction}

The elements carbon, hydrogen, and nitrogen are derived from the air and water [9]. Nitrogen, phosphorus, potassium, calcium, magnesium, sulfur, iron, zinc, manganese, copper, boron, molybdenum, cobalt, and chlorine are derived from the reserves in the soil or through applications of manures and fertilizers. The nutrients which are required in large quantities are major nutrients; those that are needed in smaller, but appreciable quantities are the secondary nutrients. The micronutrients or trace elements are those that are required in very small quantities [9].

\section{Estimation of $\mathrm{N}_{2}$ - fixation}

Several methods are used to estimate $\mathrm{N}_{2}$ fixation in legumes and the choice of the method depends on the legume species, the nature of the experiment, the experimental site [6] and the non - fixing reference plants [4]. Major methods used to measure the amount of $\mathrm{N}$ - fixed include: dry matter yield, acetylene reduction assay, xylem urede assay, $\mathrm{N}$ difference method and the ${ }^{15} \mathrm{~N}$ natural abundance method [6] The ${ }^{15} \mathrm{~N}$ natural abundance method was the method used in the current study. The ${ }^{15} \mathrm{~N}$ natural abundance method is based on differences in the natural abundance of the stable $\mathrm{N}$ - isotopes $\left({ }^{14} \mathrm{~N}\right.$ and $\left.{ }^{15} \mathrm{~N}\right)$ in the atmosphere and the other sources of $\mathrm{N}$ (e.g. soil) [10]. The heavier isotope $\left({ }^{15} \mathrm{~N}\right)$ occurs less in the atmosphere (0.3663\%) compared to the ${ }^{14} \mathrm{~N}$ isotope which is (99.6334\%) [8]. Most soils are enriched in ${ }^{15} \mathrm{~N}$ due to discrimination against this isotope during volatilization and denitrification. As a result, the heavier isotope can accumulate in the soil with time and thus gain a positive delta $(\delta){ }^{15} \mathrm{~N}$ value as it becomes enriched $[6,7]$. The ${ }^{15} \mathrm{~N}$ natural abundance of the soil $\mathrm{N}$ taken up by the legume is estimated by measuring the ${ }^{15} \mathrm{~N}$ value of a suitable non - fixing reference plant with the assumption that the rooting pattern of the test legume and the reference plants are similar [6]. Although this method is widely used and considered reliable, it has its own limitations. It is expensive as it requires costly equipment (spectrometer), it can easily be contaminated by ${ }^{15} \mathrm{~N}$ enriched materials if great care is not taken while preparing the sample, and it is reliant on the availability of suitable reference plants [11].

For many centuries, African smallholder farmers have included pulse legumes including cowpea, Bambara groundnut, groundnut

Citation: Makkies David Lengwati. "Standardized Methods were Established to Measure Symbiotic Nitrogen Fixation in the Various Land-Use System of Planting Legumes Under Field Conditions Calculations of Symbiotic Nitrogen Fixation Accumulation When One Land-Use Type is Converted to Another Crop Rotation". Acta Scientific Agriculture 5.9 (2021): 42-52. 
Standardized Methods were Established to Measure Symbiotic Nitrogen Fixation in the Various Land-Use System of Planting Legumes Under Field Conditions Calculations of Symbiotic Nitrogen Fixation Accumulation When One Land-Use Type is Converted to Another Crop Rotation

and mungbean in their cropping systems. In South Africa, these crops are included as sole or intercrops to cereals such as sorghum and maize. Off late, local farmers do not dedicate large farming space to pulses, this is reserved for cereal crops which are the main crops and staple food. Furthermore, most farmers grow pulses for household use and those that have produce on a large scale sell their produce locally and to retail markets. Interestingly, across the world records indicate an increase in area established pulses (Foyer., et al. 2016). Majority of smallholder farmers cultivate pulse legumes from December through to February. Planting in December is considered as early planting, planting in January is considered as planting during normal time whilst planting in February is considered as planting late in the cropping season. In general terms, early planting (as soon as there is enough moisture in soils) of crops is recommended in order to allow time for the crops to mature before the end of the rainy season (Serraj., et al. 2003).

These pulse legumes form a minor part of human diets because they contain vitamins, proteins and mineral nutrients particularly micronutrients. For example, the green leaves and grain of cowpea contain proteins, carbohydrates, vitamins, carotene and minerals, and therefore play an important role in improving the food and nutrition security of households (Davis, 2000). There are differences in mineral accumulation between leaves and grains of the cowpea crop (Belane and Dakora, 2011). Interestingly, there are differences in choice either leaf or grain in consumption of cowpea in South Africa. In the Northern part of the country, people prefer the leaves whilst in the East and Southern parts, people prefer the grain. In general, the fresh young and tender leaves and immature pods are regularly harvested and eaten as vegetables in households of farmers. Similarly, these fresh organs of cowpea are picked and sold at various local and international markets. The leaves can be mixed with groundnut or coconut, boiled and served as a vegetable dish. An old age practice includes collecting cowpea leaves, these are boiled and immediately dried in the sun, kept in sacks or other containers for later use in preparing dishes such as "umfuso" in the Mpumalanga Province of South Africa and in Swaziland. The dry grains on the other hand are used for several purposes such as snacks and main meal dishes including soups. For commercial use, cowpea grain is ground into flour and mixed with salt, water and onion to make a cake called "badjiya" which is widely sold in local Mozambican markets. The grain is also processed into flour for baking or making paste, a primary ingredient for "akara" (Bulgarelli., et al. 1988).
Groundnut are produced by both smallholder and commercial farmers. After harvest and shelling of grain, the remaining stover is used to feed livestock. Alternatively, the stover is incorporated into soils to enhance soil fertility. The crop has many uses as a source of food, feed and fuel. As food, the groundnut grain has multiple uses. The fresh grain is boiled and eaten as a snack, but is also boiled and used as a soup. The dry grain is roasted and eaten as a snack, it is also ground into butter, mixed with boiling vegetables as a source of oil. The most common use in the commercial industry include its oil extracted and used for cooking, in salad oils and as an ingredient for mayonnaise and margarine production (Van Schalkwyk, 2003). The crop is therefore of great potential given its multiple uses, especially at the smallholder level. Grain South Africa (2015) reported that between the years 2005 and 2015, groundnut yields in South Africa decreased as a result of erratic production caused by unfavourable rainfall conditions. With reduced groundnut production, South African demand is met through importation of the crop from Mozambique, Malawi, India and the United States of America (Grain SA, 2015).

The grain of Bambara groundnut can be boiled and eaten as a snack but can also be used when dry after harvest where it is boiled, crushed and mixed with mealy meal. It can also be pound into flour and processed into milk (Okuzor., et al. 2010; Mohammed, Shimelis and Laing, 2016), or can be cultured into a yoghurt-like beverage drink (Jideani and Jideani, 2016; cput.ac.za/preview/research/ innovations/Bambara-groundnut-cultured-beverage). Crushed or ground grains of the legume crop are used to feed chicks whilst the leaves which are rich in $\mathrm{N}$ and $\mathrm{K}$ are therefore an excellent source of animal feed (Bamshaiye, Adegbola and Bamishaiye., 2011). After harvest, the dry stover, which mainly shoot is used as feed for livestock.

According to the Department of Agriculture, Forestry and Fisheries (DAFF) (2014), the grain of mungbean is the most commonly eaten by humans. It is enriched in proteins, amino acids, vitamins, minerals such as iron and magnesium and contains folate. Mungbean is processed and used in the production of soup, flour, and a variety of Asian foods. The grain is also used for forage, silage, hay and as feed for livestock (DAFF, 2014).

Besides their uses by humans as food and as feed for livestock, the five pulse legumes selected in this study have potential to contribute symbiotic $\mathrm{N}$ to cropping systems. For example, the shoot

Citation: Makkies David Lengwati. “Standardized Methods were Established to Measure Symbiotic Nitrogen Fixation in the Various Land-Use System of Planting Legumes Under Field Conditions Calculations of Symbiotic Nitrogen Fixation Accumulation When One Land-Use Type is Converted to Another Crop Rotation". Acta Scientific Agriculture 5.9 (2021): 42-52. 
and grain of cowpea genotypes assessed at Taung, South Africa contributed 42 - $131 \mathrm{~kg} / \mathrm{ha}$ of N (Belane., et al. 2011). Results from experiments conducted in farmers' fields in southern reported that Bambara groundnut can contribute 4 - $200 \mathrm{~kg} / \mathrm{ha}$ of N [4]. Groundnut has potential to contribute $58-188 \mathrm{~kg} / \mathrm{ha}$ of N (Mokgehle., et al. 2014). Under field conditions, mungbean fixed about 31 - 111 $\mathrm{kg} / \mathrm{ha}$ of N [12]. In a pot experiment, Senaratne and Ratnasinghe (1995) reported that blackgram contributed $104-155 \mathrm{~kg} / \mathrm{ha}$ of $\mathrm{N}$.

From this background which is largely based on results from crops established without application of fertilisers, it can be said that, cowpea, Bambara groundnut, groundnut, mungbean and blackgram can each contribute more than $100 \mathrm{~kg} / \mathrm{ha}^{-1}$ of $\mathrm{N}$ to the soil. Given that in South Africa, majority of smallholder farmers that cultivate pulses are unemployed, depend on government grants, old age pension, and female household (Cook, 2017; Mpai and Maseko, 2018), low-input in their cropping systems is common. There is therefore a need to evaluate the contribution by the selected five grain legumes for $\mathrm{N}_{2}$ fixation and $\mathrm{N}$ contribution where grown in the same field. Knowledge on this could provide a biological remedy to can overcome $\mathrm{N}$ limitation in low-input cropping fields. Moreover, it is likely to contribute $\mathrm{N}$ that would benefit plant growth and increase grain yields without expenditure from farmers pocket.

\section{Results and Associated Interpretation}

Variation in growth, $\mathrm{N}$ assimilation and symbiotic performance of Bambara groundnut, blackgram, cowpea, groundnut and mungbean at Nelspruit/Mbombela

The growth determined as shoot dry weight of the selected five grain legumes varied significantly at Nelspruit (Figure 1). Significantly higher shoot dry weight was shown by Bambara groundnut, followed by that shown by the groundnut. At Nelspruit, intermediate growth was revealed by cowpea whilst lowest shoot dry weight was exhibited by blackgram and mungbean (Figure 1). Shoot $\mathrm{N}$ concentration was markedly increased in groundnut and Bambara groundnut, intermediate in blackgram and cowpea, and least in mungbean (Figure 2). As to be expected, the $\mathrm{N}$ content mimicked the shoot dry weight (Figure 3). Greater aboveground plant $\mathrm{N}$ was accumulated by Bambara groundnut, followed by the groundnut. Intermediate was shown by cowpea and blackgram whilst lowest $\mathrm{N}$ content was recorded in mungbean at Nelspruit (Figure 3).

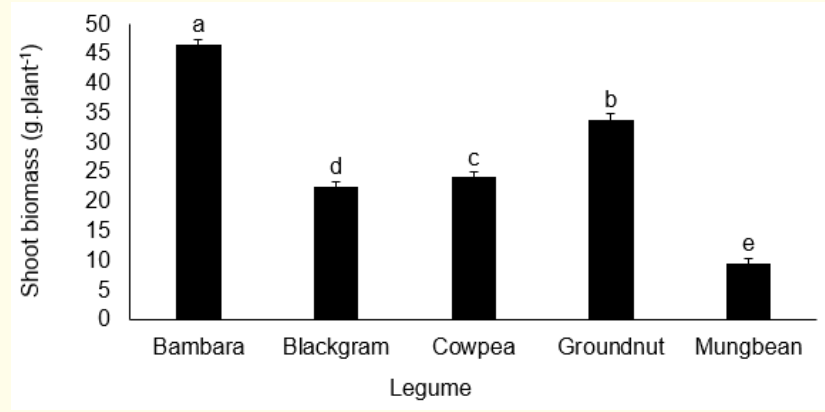

Figure 1: Shoot biomass of five legume species grown under field conditions at Nelspruit during the 2011 planting season.

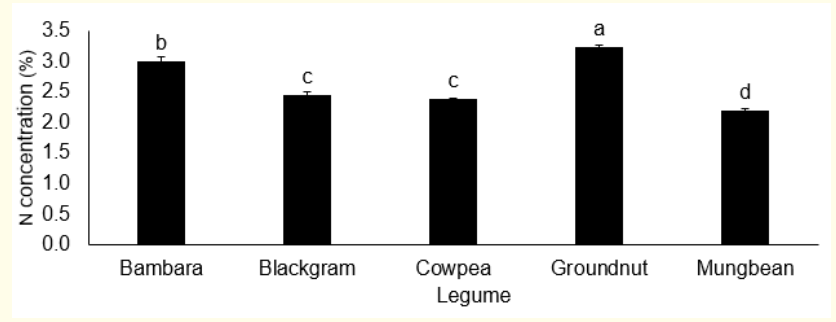

Figure 2: Shoot $\mathrm{N}$ concentration of five legume species grown under field conditions at Nelspruit during the 2011 planting season.

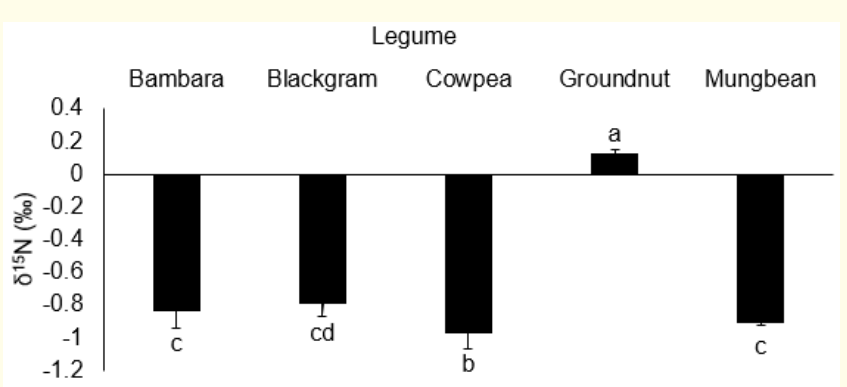

Figure 3: Shoot $\delta^{15} \mathrm{~N}$ of five legume species grown under field conditions at Nelspruit during the 2011 planting season.

Symbiotic performance was also recorded and parameters included shoot $\delta^{15} \mathrm{~N}$, shoot \%Ndfa, $\mathrm{N}$-fixed and soil $\mathrm{N}$-uptake (Figure 4 - 7). Shoot $\delta^{15} N$ varied with markedly higher revealed by groundnut, and cowpea. Bambara groundnut, blackgram and mungbean revealed the lowest mean $\delta^{15} \mathrm{~N}$ values at Nelspruit (Figure 4). The shoot \%Ndfa, which show dependence of the plant species on at- 
mospheric $\mathrm{N}_{2}$ was significantly higher in mungbean, followed by that in Bambara groundnut and cowpea. Low dependence on $\mathrm{N}_{2}$ fixation at Nelspruit was shown by blackgram and lowest was recorded in groundnut (Figure 4). The amount of $\mathrm{N}$ contributed by each of the test grain legumes at Nelspruit in 2012 was determined through calculating N-fixed (Figure 5). Bambara groundnut contributed the most $\mathrm{N}$ compared to groundnut and mungbean. Blackgram and cowpea had significantly lowest N-fixed at Nelspruit in 2012 (Figure 5). In fact, blackgram and cowpea showed $\mathrm{N}$-fixed that was greater than two-fold less that shown by Bambara groundnut at Nelspruit (Figure 5). Soil N-uptake, a measure of dependence on soil $\mathrm{N}$, was determined and compared between the species grown at Nelspruit (Figure 6). The highest soil N-uptake was shown by groundnut, followed by Bambara groundnut and blackgram. In contrast, cowpea and mungbean exhibited the least soil N-uptake at Nelspruit (Figure 6).

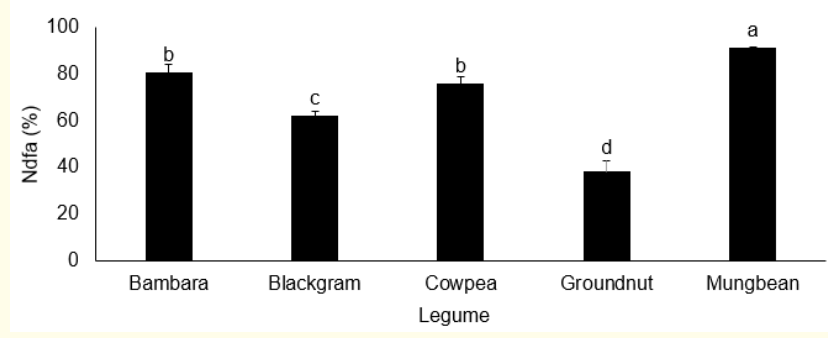

Figure 4: \%Ndfa of shoots of five legume species grown under field conditions at Nelspruit during the 2011 planting season.

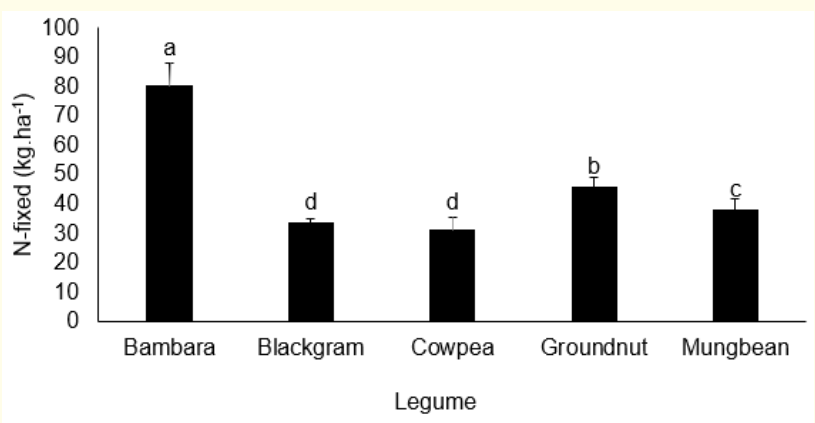

Figure 5: Amounts of N-fixed in shoots of five legume species grown under field conditions at Nelspruit during the 2011 planting season.

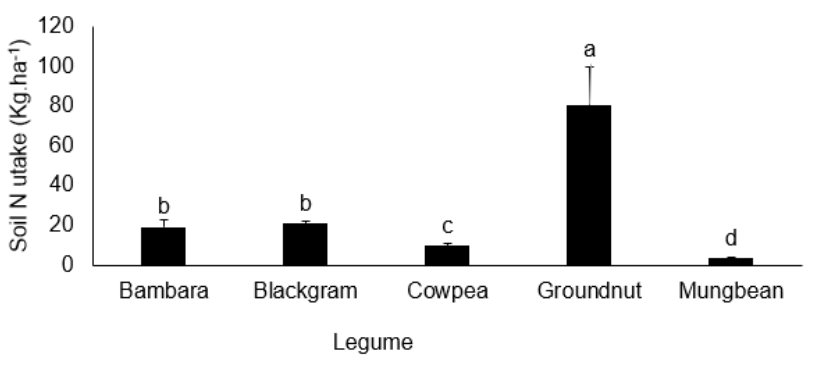

Figure 6: Amounts of soil N-uptake in shoots of five legume species grown under field conditions at Nelspruit during the 2011 planting season.

Correlation between plant growth and symbiotic performance of the grain legumes at Nelspruit:

- The correlations comparing Shoot dry weight 45 (g.plant ( $^{-1}$ ) and $\mathrm{N}$ content 1.4 (g.plant ${ }^{-1}$ ), shoot $\delta^{15} \mathrm{~N}-1.2(\%)$, shoot $\% \mathrm{Ndfa}$ 100 (\%), N-fixed $80\left(\mathrm{~kg} \mathrm{ha}^{-1}\right)$, and soil N-uptake $80\left(\mathrm{~kg}^{\mathrm{h}} \mathrm{ha}^{-1}\right)$.

- $\quad$ Correlate N content 1.4 (g.plant $^{-1}$ ) with shoot $\delta^{15} \mathrm{~N}-1.2(\%)$, shoot \%Ndfa $100(\%)$, N-fixed $80\left(\mathrm{~kg}_{\mathrm{h}} \mathrm{ha}^{-1}\right)$, and soil N-uptake 80 (kg.ha-1).

- $\quad$ Correlate shoot $\delta^{15} \mathrm{~N}-1.2(\%)$ with \%Ndfa 100 (\%), N-fixed 80 (kg.ha-1), and soil N-uptake 80 (kg.ha-1).

- $\quad$ Correlate shoot \%Ndfa $100(\%)$ with N-fixed $80\left(\mathrm{~kg}^{\mathrm{h}} \mathrm{ha}^{-1}\right)$, and soil N-uptake $80\left(\mathrm{~kg} \cdot \mathrm{ha}^{-1}\right)$.

- $\quad$ Correlate N-fixed $80\left(\mathrm{~kg} \cdot \mathrm{ha}^{-1}\right)$ with soil N-uptake 80 (kg.ha $\left.{ }^{-1}\right)$.

\section{Discussion and Data Interpretation}

Plant growth and dry matter yield

The DM yield of 5 legume species cultivars differed markedly within each legume species. At Nelspruit the shoot biomass ranged from ( $5 \mathrm{~g} /$ plant $^{-1}$ ) in legume cultivar Mungbean to (45 g/plant ${ }^{-1}$ ) in legume cultivar Bambara in 2012 (Figure 1). The legume species cultivars with great DM yield included Bambara ( $\left.45 \mathrm{~g} / \mathrm{plant}^{-1}\right)$, Groundnut (35 g/plant ${ }^{-1}$ ) and Cowpea (25 g/plant $\left.{ }^{-1}\right)$. In contrast legume species cultivar Blackgram $\left(20 \mathrm{~g} /\right.$ plant $\left.^{-1}\right)$ with the least in DM yield from Mungbean $\left(10 \mathrm{~g} /\right.$ plant $\left.^{-1}\right)$. The rest of the legume species cultivars varied in growth and biomass production. Legume species cultivars with greater biomass accumulation in 2012 included Cowpea, Groundnut and Bambara, while those with the least growth and biomass accumulation were Mungbean and Black-

Citation: Makkies David Lengwati. “Standardized Methods were Established to Measure Symbiotic Nitrogen Fixation in the Various Land-Use System of Planting Legumes Under Field Conditions Calculations of Symbiotic Nitrogen Fixation Accumulation When One Land-Use Type is Converted to Another Crop Rotation". Acta Scientific Agriculture 5.9 (2021): 42-52. 
Standardized Methods were Established to Measure Symbiotic Nitrogen Fixation in the Various Land-Use System of Planting Legumes Under Field Conditions Calculations of Symbiotic Nitrogen Fixation Accumulation When One Land-Use Type is Converted to Another Crop Rotation

gram (Figure 1). The top performing legume species cultivars at Nelspruit in 2012 were Bambara and Groundnut while those with least performing growth biomass included Mungbean, Cowpea and Blackgram (Figure 1).

\section{Shoot $\mathbf{N}$ concentration}

There were no significant differences in shoot $\mathrm{N}$ concentration between legume species cultivars planted at Nelspruit in 2011 (Figure 2). However, due to variation in plant growth shoot $\mathrm{N}$ concentration differed among the legume species cultivars, ranged from $2.0 \mathrm{~N}$ concentration (\%) in Mungbean to $3.5 \mathrm{~N}$ concentration (\%) in Groundnut (Figure 2).Legume species cultivars with greater shoot $\mathrm{N}$ concentration were Groundnut and Bambara, while those with least shoot $\mathrm{N}$ concentration were Mungbean, Cowpea and Blackgram (Figure 2). As a result, legume species Cultivars (which had greater shoot biomass) showed higher shoot $\mathrm{N}$ concentration in legume species cultivars, while Mungbean (which had the lowest shoot DM) recorded the least $\mathrm{N}$ shoot concentration (Figure 2). During the 2011 cropping season, shoot $\mathrm{N}$ concentration was reasonable at Nelspruit, with marked differences between legume species as shown in (Figure 2) $\mathrm{N}$ level concentration ranged from 2.0(\%), 2,5(\%), 3.0(\%) and 3.5(\%). Legume species cultivars with larger $\mathrm{N}$ concentration in 2012 included Groundnut, Bambara and Blackgram, while those with the least $\mathrm{N}$ shoot concentration were Cowpea and Mungbean (Figure 2).

\section{Shoot $\delta^{15} \mathrm{~N}$ of legume species cultivars}

At Nelspruit the Shoot $\delta^{15} \mathrm{~N}$ of legume species cultivars shoots varied non-significantly from $-1.2 \delta^{15} \mathrm{~N}(\%)$ in Cowpea to $+0.2 \delta^{15} \mathrm{~N}$ $(\%)$ in groundnut during the 2011 cropping season (Figure 3 ). The legume species with low $\delta^{15} \mathrm{~N}$ (i.e. high $\mathrm{N}_{2}$ fixation) in 2012 were Cowpea and Mungbean, followed by Bambara and Blackgram, while those with high $\delta^{15} \mathrm{~N}$ values (i. e low $\mathrm{N}_{2}$ fixation) included Groundnut and Blackgram. The $\delta^{15} \mathrm{~N}$ values of legume cultivars planted at Nelspruit in 2011 were generally reasonable to those commonly planted around the area and ranged from $+0.2 \delta^{15} \mathrm{~N}(\%)$ in Groundnut to $-1.2 \delta^{15} \mathrm{~N}(\%)$ in Cowpea (Figure 3). Another legume species cultivar with high $\delta^{15} \mathrm{~N}(\%)$ are Groundnut and Blackgram. Other legume species with low $\delta^{15} \mathrm{~N}(\%)$ (i.e. high $\mathrm{N}_{2}$ fixation) Bambara, Mungbean, Cowpea and Blackgram In general the $\delta^{15} \mathrm{~N}$ of legume species cultivars planted at Nelspruit in 2011 were very low (high $\mathrm{N}_{2}$ fixation) while the very high (low $\mathrm{N}_{2}$ fixation) was experienced in one legume species cultivar(Groundnut) (See figure 3).
$\%$ Nitrogen derived from atmosphere ( $\% \mathrm{~N} \mathrm{dfa)}$

The percentage $\mathrm{N}$ derived from fixation ( $\% \mathrm{Ndfa}$ ) varied non significantly between and among legume species cultivars at the experimental site. At Nelspruit only four out of five legume species cultivar tested obtained over $50 \%$ of their N nutrition from symbiotic fixation. The remaining 1 legume species cultivar derived between $0 \% \mathrm{Ndfa}$ and $40 \% \mathrm{Ndfa}$ of it's $\mathrm{N}$ from $\mathrm{N}_{2}$ fixation (Figure 4 ). As a result, the amount of symbiotic $\mathrm{N}$ in shoots also varied significantly from $40(\% \mathrm{Ndfa}), 60(\% \mathrm{Ndfa}), 70(\% \mathrm{Ndfa}), 80(\% \mathrm{Ndfa})$ and 100 (\%Ndfa) (Figure 4). In 2012 only Mungbean, Cowpea, Bambara and Blackgram could fix ( $\% \mathrm{Ndfa}$ ) of greater amount than Groundnut which fixed the least (\%Ndfa). As a result of the high \%Ndfa values in 2012, the amounts of $\mathrm{N}$-fixed were also much larger compared to lower \%Ndfa recorded by groundnut. As shown in figure 4, $\mathrm{N}$ contribution by legume species cultivars ranged from $40 \% \mathrm{Ndfa}$ to $100 \% \mathrm{Ndfa}$ (i.e. Groundnut and Mungbean). Of those only one legume cultivar could fix lesser than $50 \% \mathrm{Ndfa}$, while the remaining legume species cultivars fixed more than $40 \%$ Ndfa (See figure 4). The remaining legume species cultivar could obtain less than $50 \%$ of it's $\mathrm{N}$ nutrition from atmospheric fixation (i.e. $40 \% \mathrm{Ndfa}$ and 0 $\% \mathrm{Ndfa}$, respectively). As a result, the $\mathrm{N}$ contributions varied significantly between legume species cultivars but were much higher than those of other years.

\section{Amount of $\mathrm{N}$ fixed (kg.ha-1)}

The amount of $\mathrm{N}$ differed non-significantly among three legume species cultivars (i.e. Cowpea, Blackgram and Mungbean), whilst differed significantly between two legume species cultivars (i.e. Groundnut and Bambara) (See figure 5).

The amount of $\mathrm{N}$ fixed at Nelspruit were ranging from $30 \mathrm{~kg} . \mathrm{ha}^{-1}$ to $80 \mathrm{~kg}^{-h^{-1}}$ between Cowpea and Bambara where else Mungbean, Blackgram and Groundnut ranged Between $30 \mathrm{~kg} \cdot \mathrm{ha}^{-1}$ and $50 \mathrm{~kg}$ $\mathrm{ha}^{-1}$ (See figure 5). The amount of $\mathrm{N}$-fixed varied between $30 \mathrm{~kg} \cdot \mathrm{ha}^{-1}$ and 80 kg.ha-1 which showed considerable and reasonable amount of differences in $\mathrm{N}$-fixed amount. The amount of $\mathrm{N}$-fixed was lower than $50 \%$ in legume species cultivars Blackgram, Cowpea and Mungbean (See figure 5) whilst it was above 40\% in legume species cultivars Groundnut and Bambara. These legume species cultivars which fixed the most $\mathrm{N}$, also produced much greater biomass, while those which fixed least $\mathrm{N}$, formed the least biomass contribution. Only two legume species cultivars out of the five tested fixed more

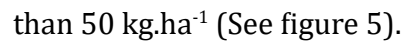


Standardized Methods were Established to Measure Symbiotic Nitrogen Fixation in the Various Land-Use System of Planting Legumes Under Field Conditions Calculations of Symbiotic Nitrogen Fixation Accumulation When One Land-Use Type is Converted to Another Crop Rotation

Legume species cultivars recorded greater biomass in this study were Bambara followed by Groundnut, Mungbean followed by Blackgram and lastly Cowpea (See figure 5). Bambara was recommended for fixing greater $\mathrm{N}$ in this study while Cowpea showed least fixing N capability. But of noticeable Groundnut N-fixing compared to Mungbean, Blackgram and Cowpea was not so much to rule such legume species cultivar outstanding to the three aforementioned. Blackgram and Cowpea shared the same $\mathrm{N}$-fixed (kg. $\mathrm{ha}^{-1}$ ) while Groundnut and Mungbean had significant difference of one level. Although Groundnut second sharing great N-fixed from Bambara but the gap was great and showed that Bambara biomass could double Groundnut biomass, if environmental factors are conducive for their growth. N-fixed by these legume species cultivars show evidence that $\mathrm{N}$ application economy can play a vital role when farmers use commercialized fertilizers.

Amount of soil N-uptake by five legume species cultivars

Soil N uptake by legume species cultivars at Nelspruit in 2012 ranged from $5 \mathrm{~kg} \cdot \mathrm{ha}^{-1}$ to $80 \mathrm{~kg} \cdot \mathrm{ha}^{-1}$ (See figure 3.6). Of the five legume species cultivars tested at Nelspruit only Four (namely, Mungbean, Cowpea, Bambara and Blackgram) derived more $\mathrm{N}$ from symbiosis than soil. The remaining one legume species cultivar was more dependent on soil $\mathrm{N}$ than symbiotic fixation for it's nutrition. Soil $\mathrm{N}$ uptake in 2012 was greater than cereal (control), with a range of $5\left(\mathrm{Kg} \mathrm{ha}^{-1}\right)$ to $80\left(\mathrm{Kg} \cdot \mathrm{ha}^{-1}\right)$ (See figure 6). In fact, one legume species cultivar took up more $\mathrm{N}$ from soil than symbiosis at Nelspruit in 2012. Of the 5 legume species cultivars tested, only four (namely, Blackgram, Bambara, Cowpea and Mungbean) showed greater dependence on $\mathrm{N}_{2}$ fixation than soil for their $\mathrm{N} \mathrm{nu}$ trition. The remaining legume species cultivar Groundnut obtained more $\mathrm{N}$ from soil than symbiosis in 2012. In 2012, soil $\mathrm{N}$ uptake by legume species cultivars varied non significantly from four legume species cultivars by $5\left(\mathrm{Kg}_{\mathrm{h}} \mathrm{h}^{-1}\right)$ to $20\left(\mathrm{Kg}^{\mathrm{h}} \mathrm{h}^{-1}\right)$, and these levels of soil $\mathrm{N}$ uptake were higher than those of Cereal (control). Four out of five legume species cultivars showed greater dependency on symbiosis than soil for their N nutrition (See figure 6). Of the evaluated legume species cultivars only one relied completely to soil for it's $\mathrm{N}$ nutrition, the rest relied more on symbiosis for their $\mathrm{N}$ nutrition. In fact, four out of the five legume species cultivars were more reliant on symbiosis than soil for their $\mathrm{N}$ nutrition, with only one legume species taking up more $\mathrm{N}$ from soil than symbiosis (See figure 6). Legume species cultivar take-up least soil N was Mungbean followed by Cowpea thereafter Bambara and Blackgram (See fig- ure 6). Legume species cultivar Groundnut was the outstanding in taking-up soil $\mathrm{N}$ for nutrition followed by Blackgram, Bambara and cowpea, whilst Mungbean was the least taking up $\mathrm{N}$ from soil (See figure 6). Amounts of soil N-uptake in shoots of five legume species grown under field conditions at Nelspruit during the 2011 planting season recorded Groundnut 80 (Kg.ha $\left.{ }^{-1}\right)$, Blackgram 20 (Kg. ha $^{-1}$ ), Bambara (20 Kg.ha- ${ }^{-1}$ ), Cowpea (10 Kg.ha-1) and Mungbean (5 Kg.ha-1) which symbolize dependency to atmospheric nitrogen fixation. As with symbiotic $\mathrm{N}$ nutrition, the legume species cultivars showed markedly strength in their levels of $\mathrm{N}$ uptake from soil at Nelspruit. The amount of soil mineral $\mathrm{N}$ taken up by legume species cultivars and $\mathrm{N}$ symbiosis nutrition at Nelspruit correlate with one another for better utilization of legumes production.

\section{Shoot $\mathbf{N}$ content of five legume species}

However, due to variation in plant growth, shoot $\mathrm{N}$ content differed among the legume species cultivars grown under field conditions at Nelspruit during the 2011 planting season. The shoot $\mathrm{N}$ content of legume species cultivars ranged from 0.2 (g.plant ${ }^{-1}$ ) to 1.4 (g.plant $^{-1}$ ) in Mungbean and Bambara (Figure 7). Legume species cultivars with greater shoot $\mathrm{N}$ content include Bambara and Groundnut, those legume species cultivars with lower shoot $\mathrm{N}$ content are Cowpea, Blackgram and Mungbean (Figure 7). The shoot $\mathrm{N}$ content of least level legume species cultivars varied between 0.2 (g.plant ${ }^{-1}$ ) and 0.6 (g.plant ${ }^{-1}$ ), while the shoot content $\mathrm{N}$ level of greater amount were 1.2 (g.plant $^{-1}$ ) and 1.4 (g.plant $^{-1}$ ) (Figure 7). The legume species cultivars Mungbean recorded 0.2 (g.plant ${ }^{-1}$ ), Blackgram 0.6 (g.plant ${ }^{-1}$ ), Cowpea 0.6 (g.plant $^{-1}$ ), while Groundnut recorded 1.2 (g.plant $^{-1}$ ) and Bambara 1.4 (g.plant ${ }^{-1}$ ) (Figure 7). Legume species cultivars with the same shoot $\mathrm{N}$ content were Blackgram and Cowpea but differed on mean standard error reading. However, shoot $\mathrm{N}$ content differed due to variation in shoot biomass. As a result, legume species cultivars Bambara and Groundnut (which had greater shoot biomass) showed higher shoot $\mathrm{N}$ content, while Mungbean, Blackgram and Cowpea (which had the lowest shoot biomass) recorded the least $\mathrm{N}$ content (Figure 7). As shown in figure $7, \mathrm{~N}$ level in shoot ranged from 0.2 (g.plant ${ }^{-1}$ ) to 1.2 (g.plant $^{-1}$ ) and 1.4 (g.plant ${ }^{-1}$ ). There were significant $(\mathrm{p} \leq 0.05$ ) differences in the N content of Mungbean, Cowpea, Groundnut and Bambara (Figure 7) of legume species cultivars grown at Nelspruit. Legume species cultivars that exhibited lower shoot $\mathrm{N}$ content were Cowpea, Blackgram and Mungbean which symbolized lower DM accumulation. However, shoot $\mathrm{N}$ content was much greater in Bam-

Citation: Makkies David Lengwati. “Standardized Methods were Established to Measure Symbiotic Nitrogen Fixation in the Various Land-Use System of Planting Legumes Under Field Conditions Calculations of Symbiotic Nitrogen Fixation Accumulation When One Land-Use Type is Converted to Another Crop Rotation". Acta Scientific Agriculture 5.9 (2021): 42-52. 
Standardized Methods were Established to Measure Symbiotic Nitrogen Fixation in the Various Land-Use System of Planting Legumes Under Field Conditions Calculations of Symbiotic Nitrogen Fixation Accumulation When One Land-Use Type is Converted to Another Crop Rotation

bara (which produced the largest biomass) followed by Groundnut (which produced the second largest biomass) then Cowpea (which produced the third largest biomass) and Blackgram (which produced the fourth largest biomass), while Mungbean (produced the least biomass) of all legume species planted. In contrast, legume species cultivars produced least shoot $\mathrm{N}$ content were the one had lower \%Ndfa (Figure 3.3) (with high $\mathrm{N}_{2}$ fixation), lower Soil N-uptake (Figure 6), lower N-fixed (Figure 5) and lower N Concentration (Figure 2) [13-31].

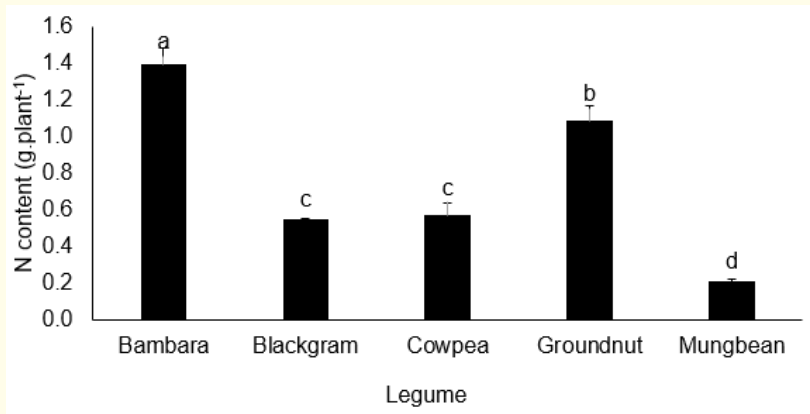

Figure 7: Shoot N content of five legume species grown under field conditions at Nelspruit during the 2011 planting season.

\section{General Conclusion and Discussion}

Plant nutrient role and requirement

Plants like other organisms, require "FOOD" for their living and growth development. From chemical elements drawn from soil, water, and air, plants build a vast array of plant products. These essential elements are plant nutrients.

\section{Nitrogen: (N)}

- An important constituent of chlorophyll, protoplasm, protein, and nucleic acids

- Increases growth and development of all living tissues

\section{Deficiency symptoms of selected nutrients}

Nitrogen deficiency:

- $\quad$ Stunted growth.

- Appearance of light - green to pale - yellow on the older leaves, starting from the tips and progressing towards the base of the leaf blade. This is followed by drying and/or dropping of the older leaves.

- In acute deficiency, flowering is greatly reduced.

- Lowers the protein content.
An interesting feature of the litchi plant is the symbiotic growth of mycorrhizal fungi on the roots of the trees. Just as bacteria live on the roots of the leguminous plants like the Egyptian clover and fix nitrogen from the air present in the soil, these fungi perform the same function in litchi. The trees and the fungus live together to the benefit of each other. These fungi form nodules on the roots of litchi. In India litchi is grown on fertile soils and manuring is generally neglected, but an application of 10 to $250 \mathrm{~kg}$ of farmyard manure per annum per tree depending upon its age is recommended. Apart from nitrogen, litchi also definitely requires potash and phosphorus (R Singh 1979 and Saka 1900).

\section{Dedication and Acknowledgement}

This article is dedicated to the passing away of Dr. C. Mathews unexpectedly in the late month of September 2020 while still hanging a lot of Tshwane University of Technology, student field work need data compiling and laboratory analysis. He showed extraordinary love and dedication in seeing science and technology advancing to the benefit of all those having scientific interpretation in their lifestyle.

The most extra-ordinary acknowledgement to Dr. Maseko T.S, whom spearheaded the lecturing and editing the dissertation and thesis written by Tshwane University of technology cupolas of BNF laboratory students and his family to allow his presence in assistance of science and technology development.

The main nutrients a plant needs are nitrogen, phosphorus and potassium (Table 1).

\section{Annexure}

Observations to be recorded:

Replicated observations (on plot basis)

1. Days to $75 \%$ emergence (DE)

2. Days to $75 \%$ flowering (DF)

3. Final plant stand (FS)

4. Days to harvest (DH)

5. Pod yield (kg/plot) (PY).

Observations to be recorded on bulk samples (on treatment basis)

6. Shelling percentage (SHP)

7. Percentage of sound mature seeds (SMS)

8. 100 seed weight (HSW)

Citation: Makkies David Lengwati. “Standardized Methods were Established to Measure Symbiotic Nitrogen Fixation in the Various Land-Use System of Planting Legumes Under Field Conditions Calculations of Symbiotic Nitrogen Fixation Accumulation When One Land-Use Type is Converted to Another Crop Rotation". Acta Scientific Agriculture 5.9 (2021): 42-52. 
Standardized Methods were Established to Measure Symbiotic Nitrogen Fixation in the Various Land-Use System of Planting Legumes Under Field Conditions Calculations of Symbiotic Nitrogen Fixation Accumulation When One Land-Use Type is Converted to Another Crop Rotation

9. Seed appearance and uniformity (SAU)

10. Pest and disease score (PDSc).

Optional observation (on bulk samples)

11. Oil content (OIL)

12. Protein content (PRO)

Appearance and diseases scoring

*Visual score on a 1 - 9 scale where 1 is excellent appearance and Uniformity and 9 is poor appearance and uniformity.

**Visual score on a 1 - 9 scale where 1 is no disease or damage and 9 is $50-100 \%$ foliage destroyed or severe damage.

\section{Bibliography}

1. Climate change working group final report, Phase II; International Centre for Research in Agroforestry (ICRAF). Carbon sequestration and trace gas emissions in slash-and-burn and alternative land uses in the humid tropics; Nairobi, Kenya (2000).

2. Davidson E A., et al. "Nitrous oxide emission controls and inorganic nitrogen dynamics in fertilized tropical agricultural soils". Soil Science Society of America Journal 60 (1996): 11451152.

3. Erickson H E and M Keller. "Tropical land-use change and soil emissions of nitrogen oxides". Soil Use and Management 13 (1997): 278-287.

4. Nyemba RC and Dakora F D. "Root exudates as mediators of mineral acquisition in low-nutrient environments". Food Security in Nutrients-Stressed Environments: Exploiting Plants' Genetic Capabilities, Springer (2005): 201-213.

5. Belane A K and F D Dakora. "Photosynthesis, symbiotic N and $\mathrm{C}$ accumulation in leaves of 30 nodulated cowpea genotypes grown in the field at Wa in the Guinea savannah of Ghana". Field Crops Research 124.3 (2011): 279-287.

6. Unkovich M. "Nitrogen fixation in Australian dairy systems: review and prospect". Crop and Pasture Science 63 (2012): 787-804.

7. Shearer G and D H Kohl. " $\mathrm{N}_{2}$-fixation in field settings: estimations based on natural $15 \mathrm{~N}$ abundance". Functional Plant Biology 13.6 (1986): 699-756.

8. Mariotti A. "Atmospheric nitrogen is a reliable standard for natural $15 \mathrm{~N}$ abundance measurements" (1983).
9. Nagur T., et al. Management procedures for pearl millet improvement. ICRISAT, Skill Development Series (1992).

10. Herridge D. "Chickpea increases soil-N fertility in cereal systems through nitrate sparing and N2 fixation". Soil Biology and Biochemistry 27 (1995): 5454-5551.

11. Spriggs A C., et al. "Influence of mycorrhizal associations on foliar $\delta 15 \mathrm{~N}$ values of legume and non-legume shrubs and trees in the fynbos of South Africa: implications for estimating N2 fixation using the $15 \mathrm{~N}$ natural abundance method". Plant and Soil 225.2 (2003): 495-502.

12. Mokobane K F. "Evaluation of symbiotic N nutrition, C accumulation, $\mathrm{P}$ uptake and grain yield of fifteen mung bean genotypes planted at two sites in South Africa". M. Tech Thesis, Tshwane University of Technology, Pretoria (2013).

13. Beck A., et al. "A new methodology and procedure for fsr/e programmes with maize and cowpeas in mpumalanga, South Africa in 1994-95".

14. Cheming'wa GN. "Nitrogen fixation potential and residual effects of selected grain legumes in a Kenyan soil". International Journal of Agronomy and Agricultural Research 3.2 (2006): 1420.

15. Chalk PM. "Methodologies for estimating nitrogen transfer between legumes and companion species in agro-ecosystems: a review of $15 \mathrm{~N}$-enriched techniques". Soil Biology and Biochemistry 73 (2014): 10-21.

16. Fuller D Q and E L Harvey. "The archaeobotany of Indian pulses: identification, processing and evidence for cultivation". Environmental Archaeology 11.2 (2006): 219-246.

17. Heuze V., et al. Mung bean (Vigna radiate)., Feedipedia, a programme by INRA, CIRAD, AFZ and FAO (2015).

18. Hoorman J., et al. "Sustainable crop rotations with cover crops". Ohio State University, Extension, Fact Sheet Agriculture and Natural Resources, SAG-9-09. (2009).

19. Hungria M and MA Vargas. "Environmental factors affecting N2 fixation in grain legumes in the tropics, with an emphasis on Brazil". Field Crops Research 65 (2000): 151-164.

20. Kay D E. Food legumes. Crop and product digest, No.3. Tropical Products Institute, London (UK): (1979): 17-25. 
21. Mathews C. Minor edible legumes in Mpumalanga, South Africa., Proceedings of first International edible legume conference in conjunction with the fourth world cowpea congress, University of Pretoria., Pretoria, Published in IELC website (2005).

22. Meulenberg, F P., et al. "African legumes a vital but under-utilized resources". Journal of Experimental Botany 61.5 (2009): 1257-1265.

23. Mokgehle S N., et al. "Variation in N2 fixation and N contribution by 25 groundnut (Arachis hypogaea L.) varieties grown in different agro-ecologies, measured using $15 \mathrm{~N}$ natural abundance". Agriculture, Ecosystems and Environment 195 (2014): 161-172.

24. Montanez A., et al. "The effect of temperature on nodulation and nitrogen fixation by five Brandyrhizobium japonicum strains". Applied Soil and Ecology 2.3 (1995): 165-174.

25. Pearson K. "On lines and planes of closest fit to systems of points in space". Philosophical Magazine Sixth Series 2 (1901): 559-572.

26. Ranjit Singh. India-the land and people., fruits., Second edition (Reprint) 1979 (Saka 1900).

27. Reckling M. “A cropping system assessment framework-evaluating effects of introducing legumes into crop rotations". European Journal of Agronomy 76 (2016): 186-197.

28. Singh S K and Jakhar. "Study on Constraints and Adoption of Black Gram Production Technology by the Farners in Mirzapur District of Uttar Pradesh, India". International Journal of Current Microbiology and Applied Sciences 6.10 (2017): 174178.

29. van Averbeke $\mathrm{W}$ and S Yoganathan. Using Kraal Manure as a Fertiliser., National Department of Agriculture and the Agricultural and Rural Development Research Institute, Fort Hare (1997).

30. Wester Robert E. Growing vegetables in the home garden. Home and Garden Bulletin No. 202. U.S. Department of Agriculture (1972).

31. Zahran HH. "Rhizobium-legume symbiosis and nitrogen fixation under severe conditions and in an arid climate". Microbiology and Molecular Biology Reviews 63.4 (1999): 968-989.

\section{Assets from publication with us}

- Prompt Acknowledgement after receiving the article

- Thorough Double blinded peer review

- Rapid Publication

- Issue of Publication Certificate

- High visibility of your Published work

Website: www.actascientific.com/

Submit Article: www.actascientific.com/submission.php

Email us: editor@actascientific.com

Contact us: +919182824667 